Supporting Information for

\title{
Facile and Efficient Patterning Method for Silver Nanowires and Its Application to Stretchable Electroluminescent Displays
}

Yong Lin ${ }^{a, b}$, Wei Yuan ${ }^{b, *}$, Chen Ding ${ }^{b}$, Shulin Chen ${ }^{b}$, Wenming Su ${ }^{b}$, Hailong Hu ${ }^{a}$, Zheng Cui ${ }^{b}$,

Fushan $L i$ a,

a Institute of Optoelectronic Technology, Fuzhou University, Fuzhou 350002, China.

${ }^{b}$ Printable Electronics Research Centre, Suzhou Institute of Nano-Tech and Nano-Bionics, Chinese Academy of Sciences, Suzhou 215123, China.

\section{Corresponding Author}

*E-mail: wyuan2014@sinano.ac.cn. (W. Yuan)

*E-mail: fsli@,fzu.edu.cn. (F. Li) 
Table S1. Patterning methods for AgNWs in recent years

\begin{tabular}{|c|c|c|c|c|c|c|c|}
\hline \multicolumn{2}{|c|}{ Methods } & \multirow{2}{*}{$\begin{array}{l}\text { AgNWs size } \\
\text { D: } 60 \mathrm{~nm} \\
\text { L: } 6 \mu \mathrm{m}\end{array}$} & \multirow{2}{*}{$\begin{array}{l}\begin{array}{l}\text { Patterning } \\
\text { resolution }\end{array} \\
\text { Process } \\
\text { area } \\
14 \mathrm{~mm}^{2} \\
\end{array}$} & \multirow{4}{*}{$\begin{array}{l}\text { Destroy } \\
\text { Ag NW? } \\
\text { No }\end{array}$} & \multirow{4}{*}{$\begin{array}{l}\text { Disadvantage } \\
\text { Low resolution, high } \\
\text { roughness of } \\
\text { pattern's edge and } \\
\text { unable to implement } \\
\text { complex pattern }\end{array}$} & \multirow{4}{*}{$\begin{array}{l}\text { Advantage } \\
\begin{array}{l}\text { simple and cost- } \\
\text { effective }\end{array}\end{array}$} & \multirow{2}{*}{$\begin{array}{l}\text { Ref } \\
1\end{array}$} \\
\hline \multirow[t]{3}{*}{$\begin{array}{l}\text { Mask } \\
\text { assisti } \\
\text { ng }\end{array}$} & Drop casting & & & & & & \\
\hline & Spray coating & $\begin{array}{l}\text { D: } 115 \mathrm{~nm} \\
\mathrm{~L}: 30 \mu \mathrm{m}\end{array}$ & $\begin{array}{l}\text { Process } \\
\text { area } \\
13 * 13 \mathrm{~cm}^{2}\end{array}$ & & & & 2 \\
\hline & $\begin{array}{l}\text { Mayer-rod } \\
\text { coating }\end{array}$ & $\begin{array}{l}\text { D: } 223 \mathrm{~nm} \\
\mathrm{~L}: 143 \mu \mathrm{m}\end{array}$ & $\begin{array}{l}\text { Process } \\
\text { area } \\
\text { Less than } \\
3 * 3 \mathrm{~cm}^{2}\end{array}$ & & & & 3 \\
\hline \multirow{2}{*}{\multicolumn{2}{|c|}{ Photolithography }} & $\begin{array}{l}\text { D: } 20 \sim 40 \mathrm{~nm} \\
\text { L: } 10 \sim 20 \mu \mathrm{m}\end{array}$ & $20 \mu \mathrm{m}$ & \multirow[t]{2}{*}{ Yes } & \multirow{2}{*}{$\begin{array}{l}\text { multiple processing } \\
\text { steps and expensive } \\
\text { equipment }\end{array}$} & \multirow[t]{2}{*}{ High resolution } & 4 \\
\hline & & $\begin{array}{l}\text { D: } 115 \mathrm{~nm} \\
\mathrm{~L}: 20 \sim 50 \mu \mathrm{m}\end{array}$ & $15 \mu \mathrm{m}$ & & & & 5 \\
\hline \multicolumn{2}{|c|}{ Laser ablation } & $\begin{array}{l}\text { D: } 70 \sim 100 \mathrm{~nm} \\
\mathrm{~L}: 100 \sim 150 \mu \mathrm{m}\end{array}$ & $30 \mu \mathrm{m}$ & Yes & $\begin{array}{l}\text { destroy the one- } \\
\text { dimensional wire } \\
\text { structure of AgNWs }\end{array}$ & High resolution & 6 \\
\hline \multirow{2}{*}{\multicolumn{2}{|c|}{$\begin{array}{l}\text { Substrate surface } \\
\text { treatment }\end{array}$}} & $\begin{array}{l}\text { D: } 125.7 \mathrm{~nm} \\
\mathrm{~L}: 19.8 \mu \mathrm{m}\end{array}$ & $8 \mu \mathrm{m}$ & \multirow[t]{2}{*}{ No } & \multirow{2}{*}{$\begin{array}{l}\text { only be used on } \\
\text { hydrophobic } \\
\text { substrates, poor edge } \\
\text { smoothness }\end{array}$} & \multirow[t]{2}{*}{ High resolution } & 7 \\
\hline & & $\begin{array}{l}\text { D: N/A } \\
\text { L: } 10 \sim 20 \mu \mathrm{m}\end{array}$ & $150 \mu \mathrm{m}$ & & & & 8 \\
\hline \multicolumn{2}{|c|}{ Stamping dry transfer } & $\begin{array}{l}\text { D: } 75 \mathrm{~nm} \\
\mathrm{~L}: 12.5 \mu \mathrm{m}\end{array}$ & $1 \mathrm{~mm}$ & No & $\begin{array}{l}\text { Low resolution, } \\
\text { target substrate must } \\
\text { has enough adhesion }\end{array}$ & Low-cost, simple & 9 \\
\hline \multirow{2}{*}{\multicolumn{2}{|c|}{$\begin{array}{l}\text { Micro-channel self- } \\
\text { assemble }\end{array}$}} & $\begin{array}{l}\mathrm{D}: 27 \mu \mathrm{m} \\
\mathrm{L}: 22 \mu \mathrm{m}\end{array}$ & $100 \mu \mathrm{m}$ & \multirow[t]{2}{*}{ No } & \multirow{2}{*}{$\begin{array}{l}\text { Time consuming and } \\
\text { hardly applicable for } \\
\text { complex pattern and } \\
\text { large-area fabrication }\end{array}$} & \multirow{2}{*}{$\begin{array}{l}\text { Low-cost and } \\
\text { simple, high } \\
\text { resolution }\end{array}$} & 10 \\
\hline & & $\begin{array}{l}\mathrm{L}: 150 \text { and } 25 \\
\mu \mathrm{m}\end{array}$ & $\begin{array}{l}25 \text { and } 10 \\
\mu \mathrm{m}\end{array}$ & & & & 11 \\
\hline \multirow[t]{6}{*}{$\begin{array}{l}\text { Printi } \\
\text { ng }\end{array}$} & Gravure & $\begin{array}{l}\mathrm{D}: 33 \mathrm{~nm} ; \mathrm{L}: 14 \\
\mu \mathrm{m}\end{array}$ & $\mathrm{N} / \mathrm{A}$ & \multirow[t]{6}{*}{ No } & \multirow{6}{*}{$\begin{array}{l}\text { Need to adjust the } \\
\text { experimental } \\
\text { parameters } \\
\text { repeatedly, printing } \\
\text { nozzle and screen } \\
\text { mesh tend to clog } \\
\text { easily }\end{array}$} & \multirow{6}{*}{$\begin{array}{l}\text { High resolution, } \\
\text { achieve large- } \\
\text { area production }\end{array}$} & 12 \\
\hline & $\begin{array}{l}\text { Electrohydrody } \\
\text { namic }\end{array}$ & $\begin{array}{l}\mathrm{D}: 120 \mathrm{~nm} ; \mathrm{L}: 25 \\
\mu \mathrm{m}\end{array}$ & $45 \mu \mathrm{m}$ & & & & 13 \\
\hline & Laser & $\begin{array}{l}\mathrm{D}: 100 \mathrm{~nm} ; \mathrm{L}: 20 \\
\mu \mathrm{m}\end{array}$ & $100 \mu \mathrm{m}$ & & & & 14 \\
\hline & Inject & $\begin{array}{l}\mathrm{D}: 55 \mathrm{~nm} ; \mathrm{L}: 8.1 \\
\mu \mathrm{m}\end{array}$ & $1 \mathrm{~mm}$ & & & & 15 \\
\hline & Screen & $\begin{array}{l}\mathrm{D}: 25 \sim 35 \mathrm{~nm} ; \\
\mathrm{L}: 15 \sim 25 \mu \mathrm{m}\end{array}$ & $50 \mu \mathrm{m}$ & & & & 16 \\
\hline & Direct-writing & $\begin{array}{l}\mathrm{D}: 60 \mathrm{~nm} ; \mathrm{L}: 15 \\
\mu \mathrm{m}\end{array}$ & $500 \mu \mathrm{m}$ & & & & 17 \\
\hline \multicolumn{2}{|c|}{$\begin{array}{l}\text { Vacuum filtration and } \\
\text { mask }\end{array}$} & $\begin{array}{l}\mathrm{D}: 70 \mathrm{~nm} ; \mathrm{L}: 60 \\
\mu \mathrm{m}\end{array}$ & $250 \mu \mathrm{m}$ & No & $\begin{array}{l}\text { roughness of edges, } \\
\text { unable to prepare } \\
\text { complex pattern, } \\
\text { patterns are easy } \\
\text { broken when peeling } \\
\text { off the mask }\end{array}$ & Low-cost, simple & 18 \\
\hline
\end{tabular}



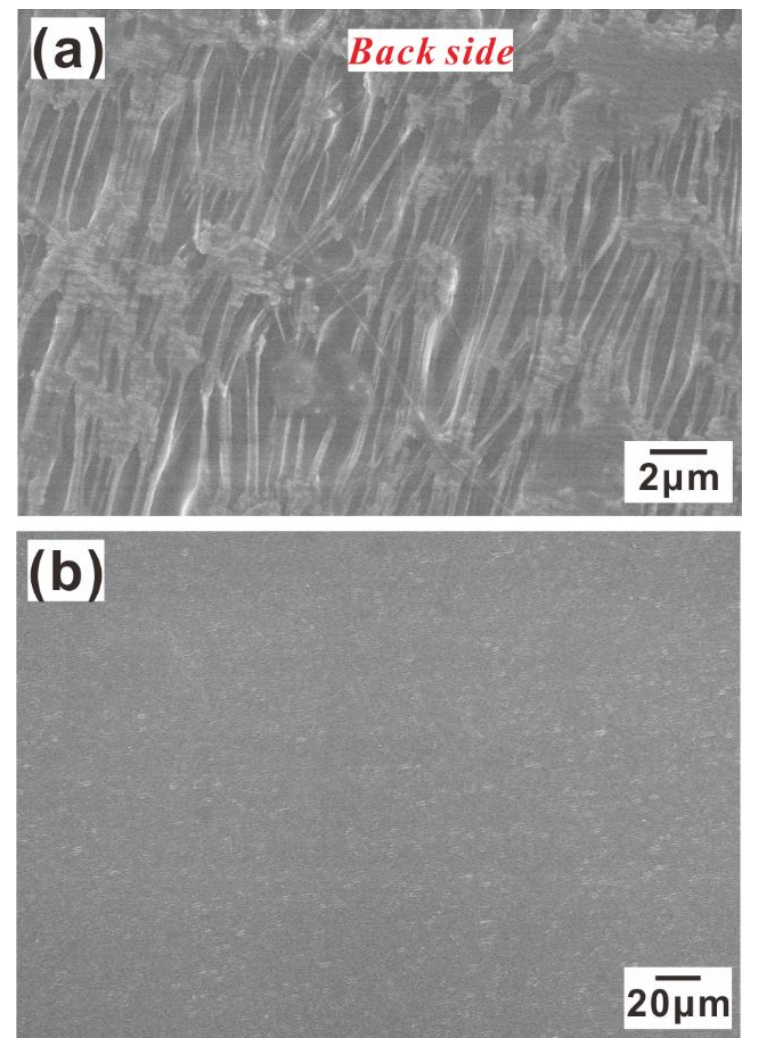

Figure S1. (a) SEM image of the back side of PDMS covered area; (b) SEM image of the surface of PDMS covered area after AgNWs deposition
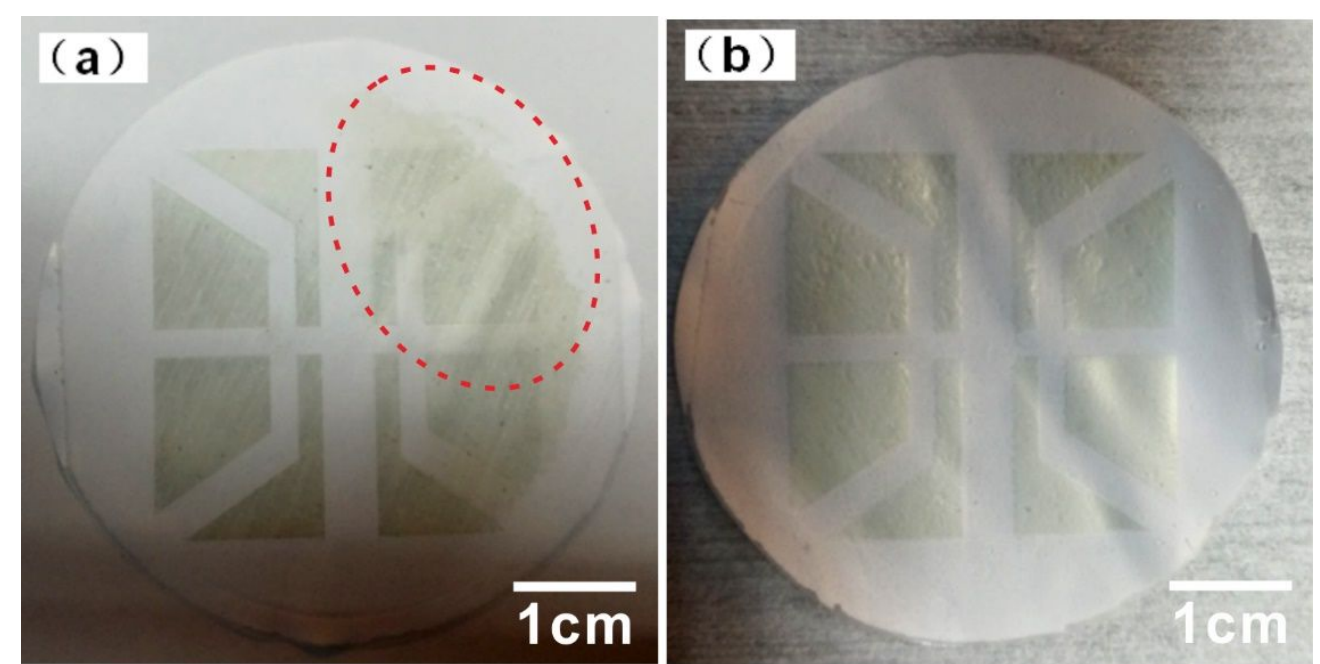

Figure S2. AgNWs pattering with (b) and without (a) membrane pre-treatment of oxygen plasma. The red dotted mark in (a) indicates the destruction of AgNWs pattering. 


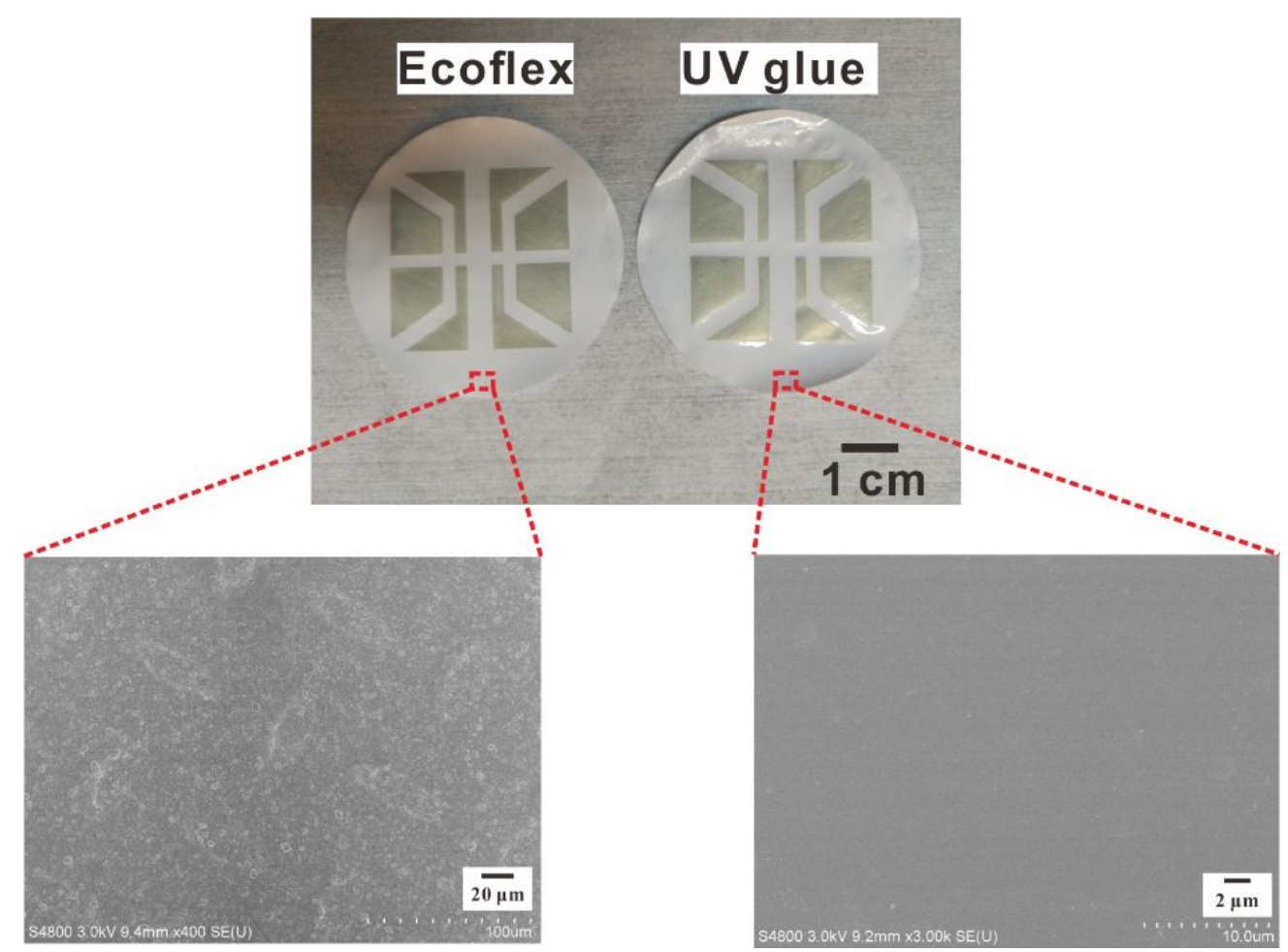

Figure S3. Photograph of AgNWs patterns deposited on PTFE membranes with Ecoflex and UV glue masks (upper), and SEM images of surface morphology of printed Ecoflex layer and UV resin layer (lower).
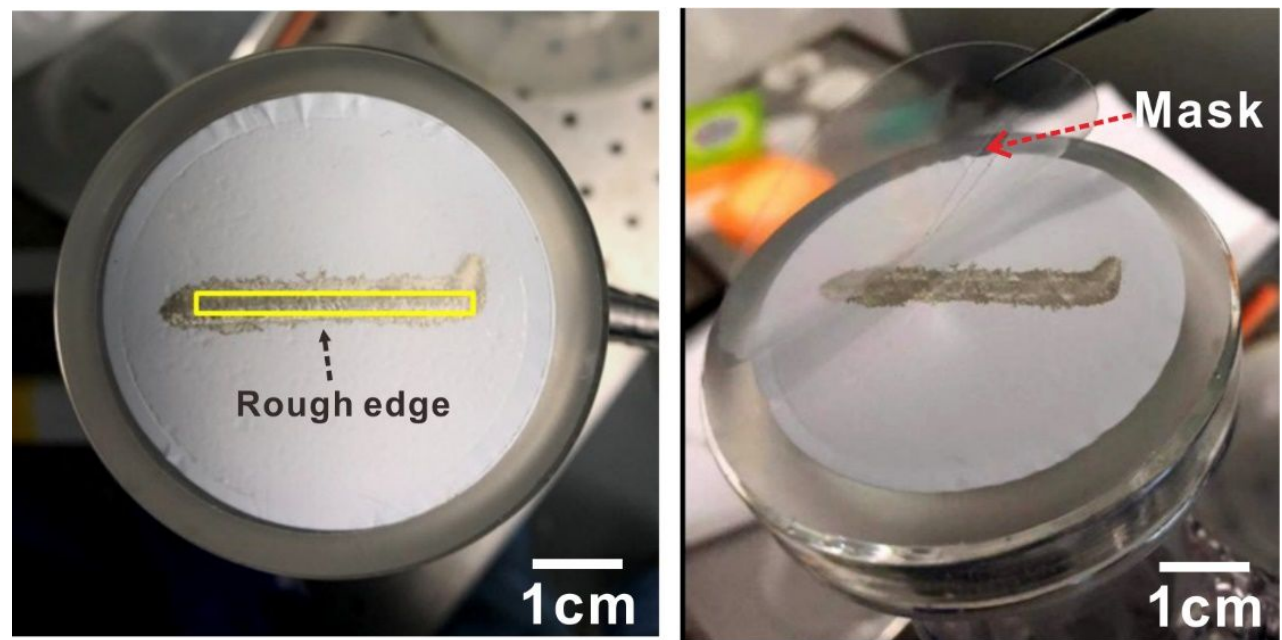

Figure S4. AgNWs pattern fabricated by vacuum filtration combining with PET mask. 


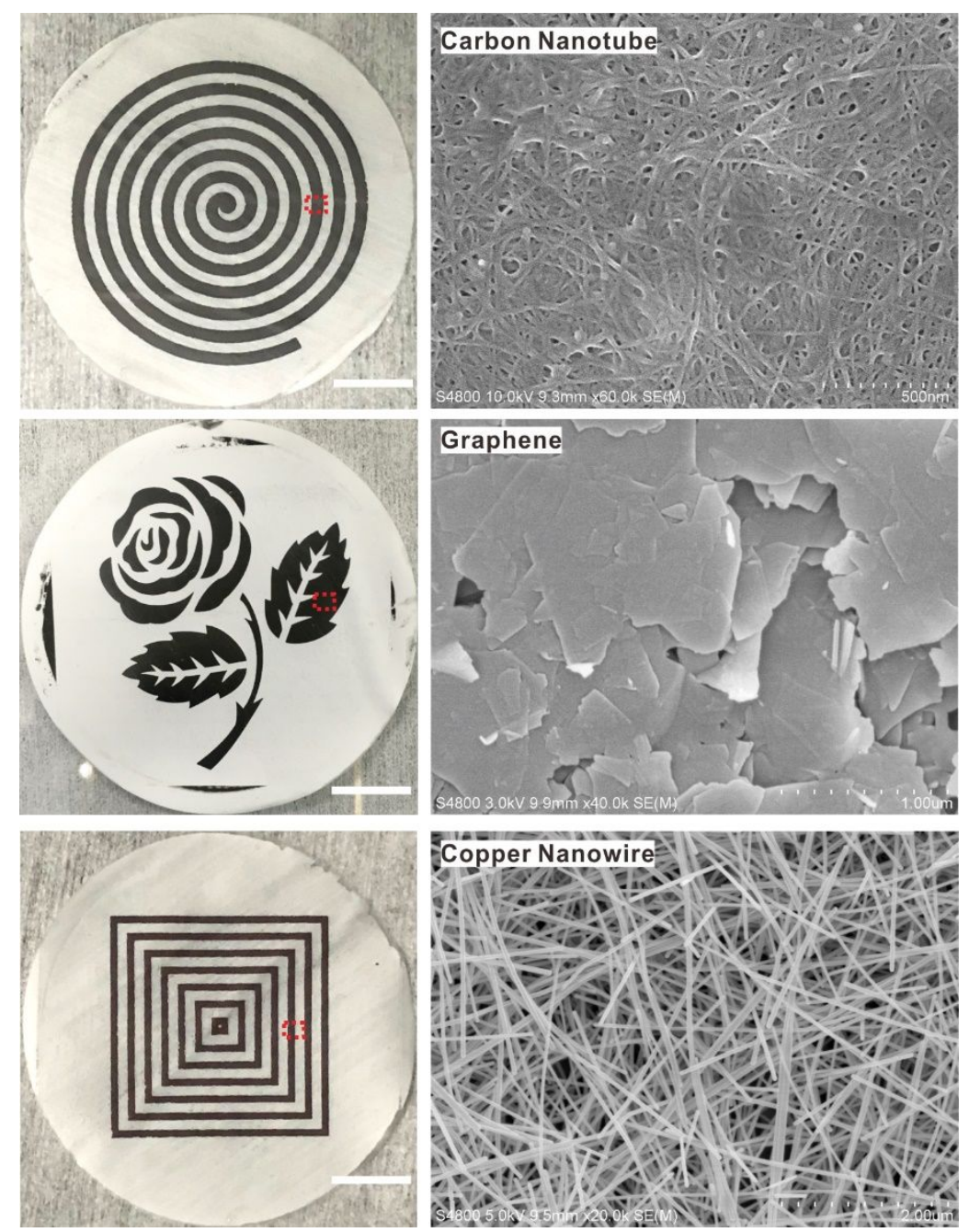

Figure S5. Patterns of various nanomaterials (Carbon Nanotubes, Graphene, Copper nanowires) with complex shapes and corresponding SEM images. Scale bar is $1 \mathrm{~cm}$.
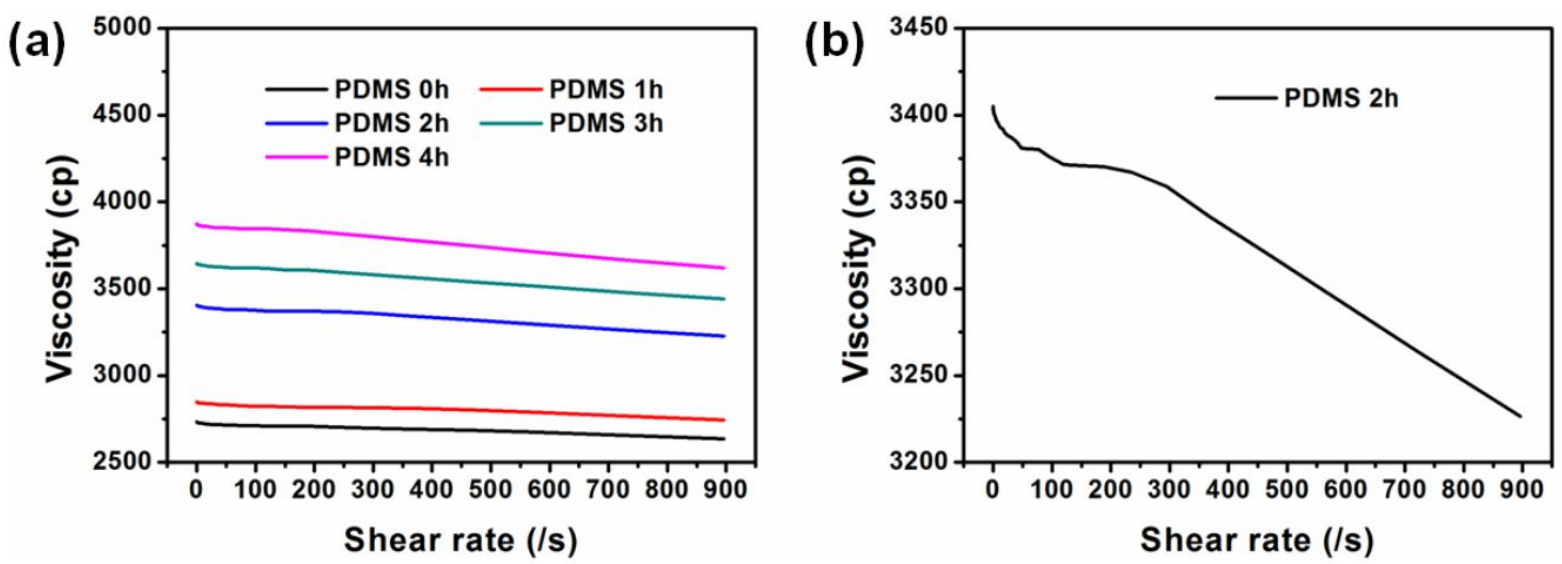

Figure S6. (a) Rheological behavior of PDMS inks crosslinked at room temperature for different times; (b)

Viscosity of PDMS ink crosslinked at room temperature for 2 hours as function of shear rate. 

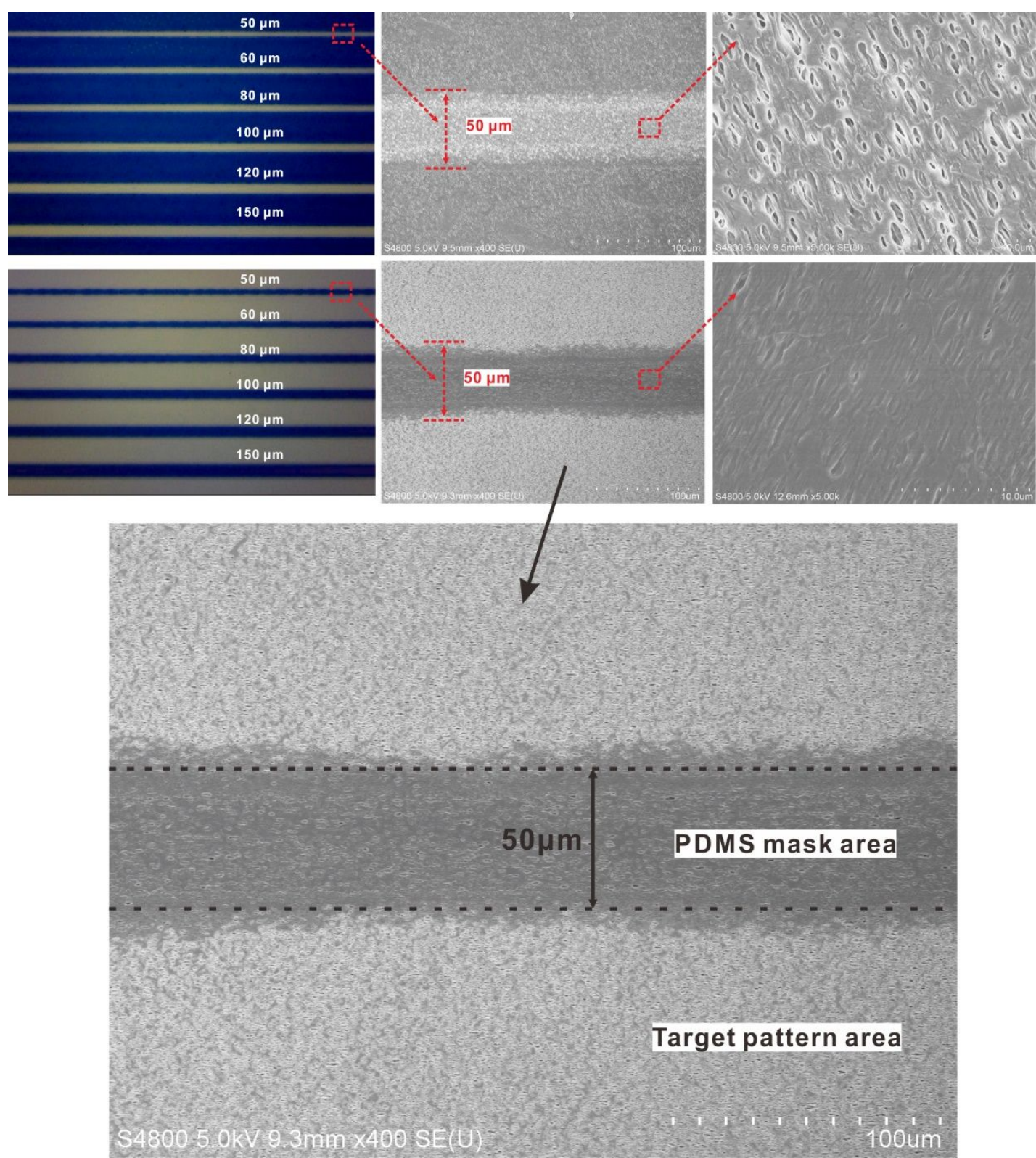

Figure S7. Microscopic photos and SEM images of printed PDMS mask with different line width and line spacing. 


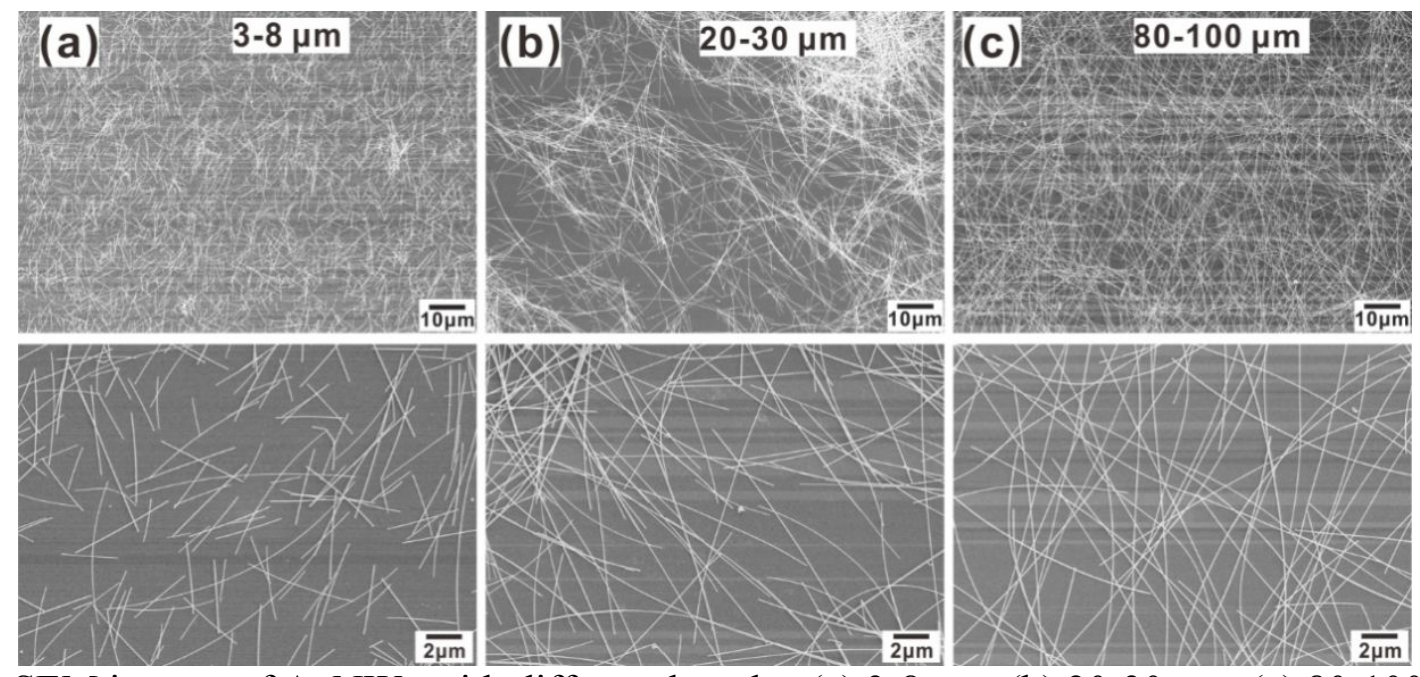

Figure S8. SEM images of AgNWs with different lengths. (a) 3-8 $\mu \mathrm{m}$, (b) $20-30 \mu \mathrm{m}$, (c) $80-100 \mu \mathrm{m}$

3-8 $\mu \mathrm{m}$
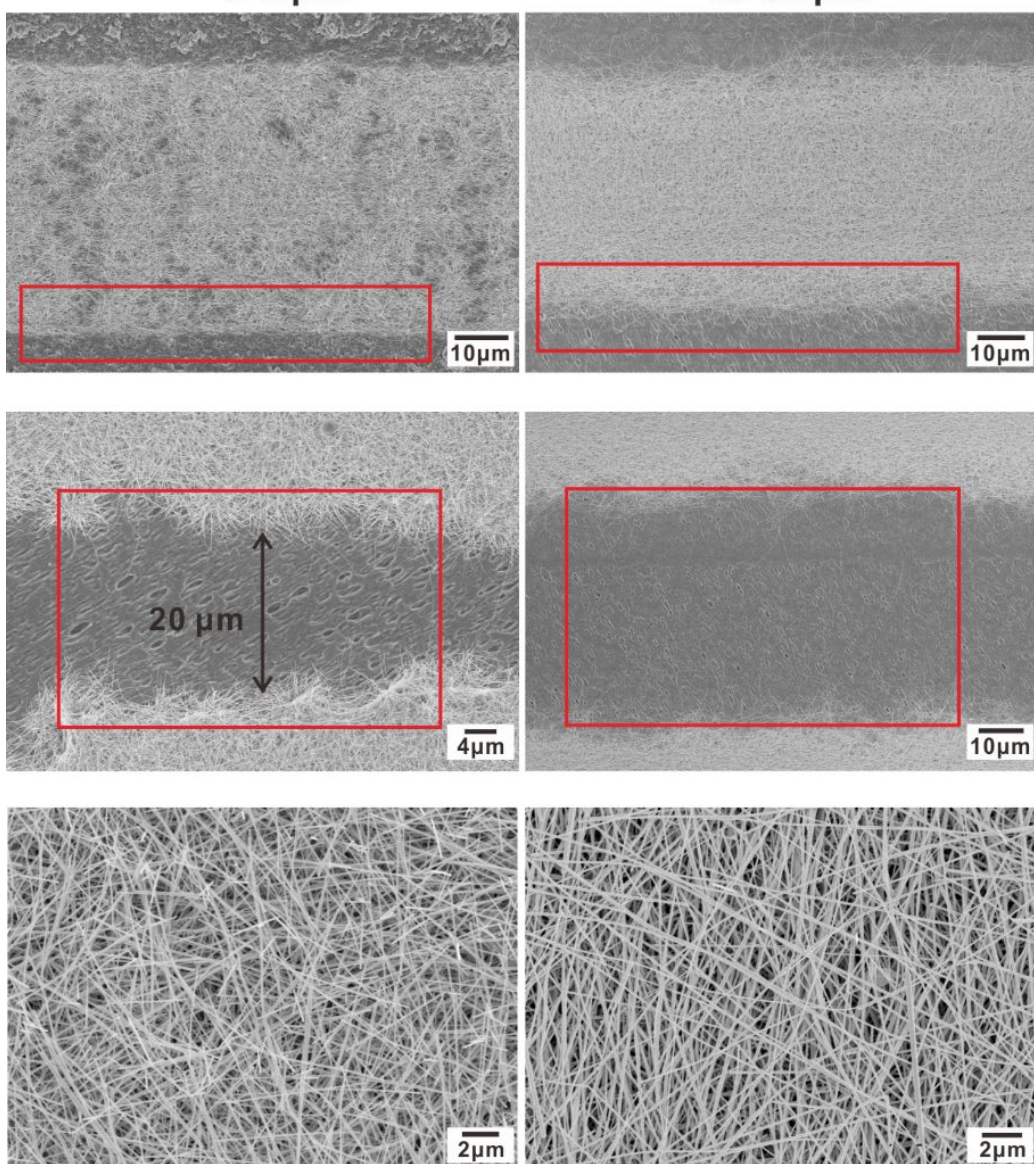

20-30 $\mu \mathrm{m}$
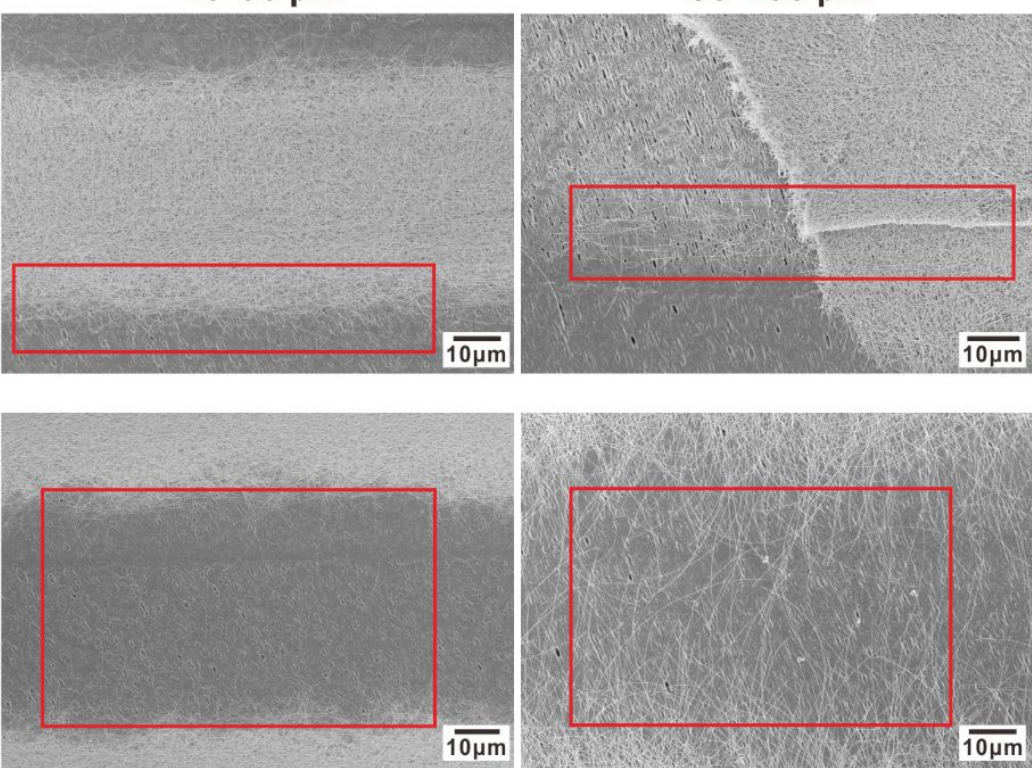

$\overline{10 \mu \mathrm{m}}$

Figure S9. SEM images of three kinds of AgNWs deposited on the membranes with the same printing mask of $50 \mu \mathrm{m}$ line width and line spacing. 


\section{Positive structural pattern}

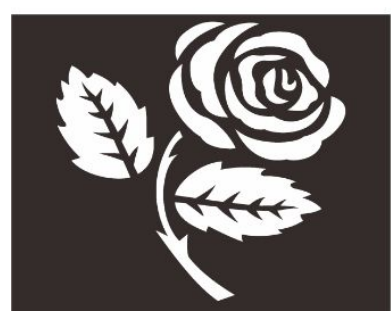

Inverse structural pattern

Figure S10. The definition of positive and inverse structural patterns

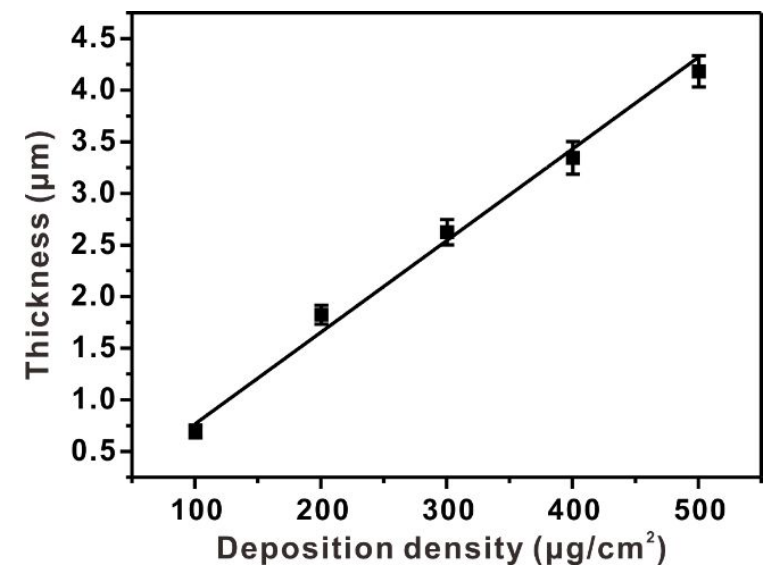

Figure S11. The thickness of AgNWs films as function of deposition densities. 

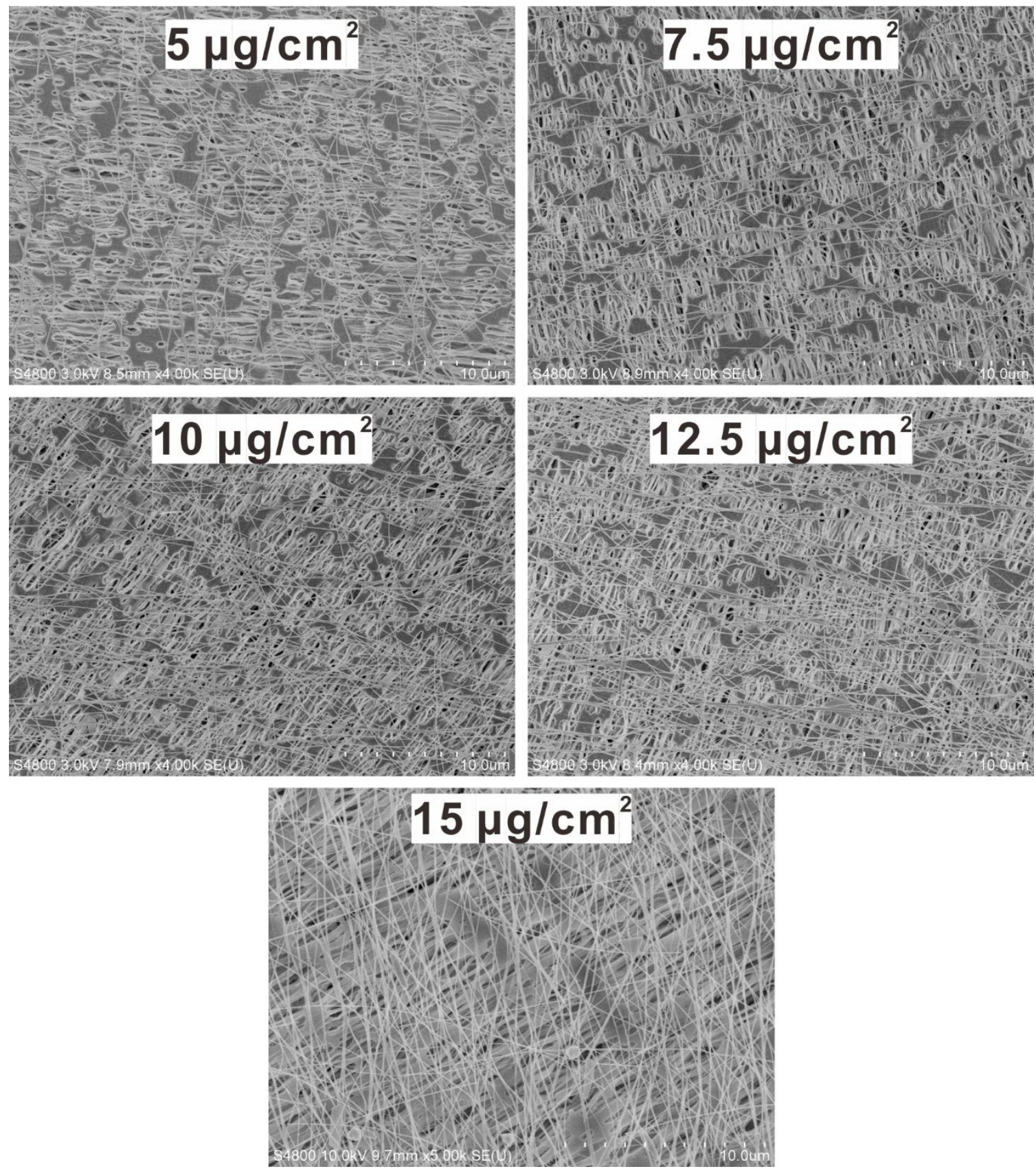

Figure S12. SEM images of the AgNWs films with different deposition densities $\left(\leq 15 \mu \mathrm{g} / \mathrm{cm}^{2}\right)$. 


\section{(a)}

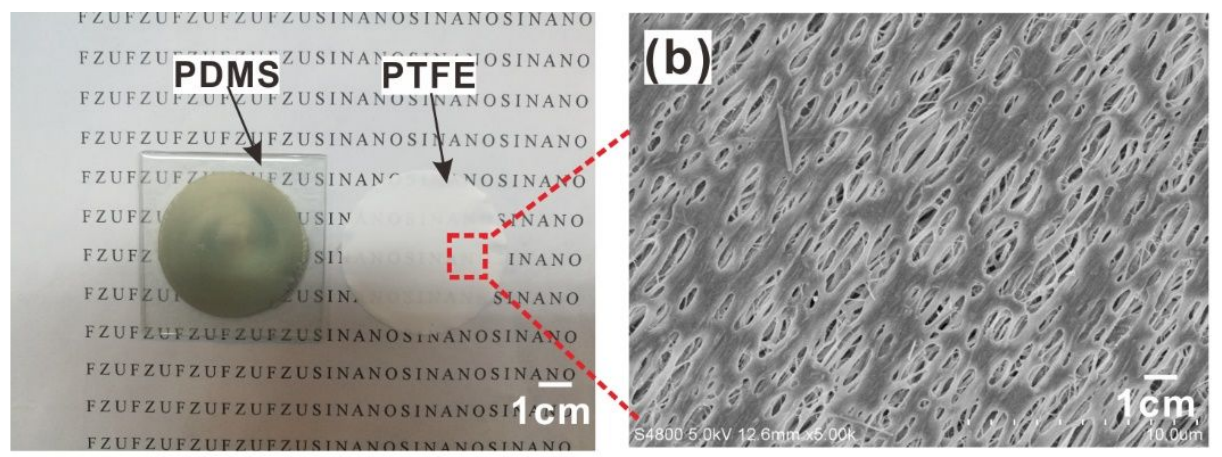

(c)
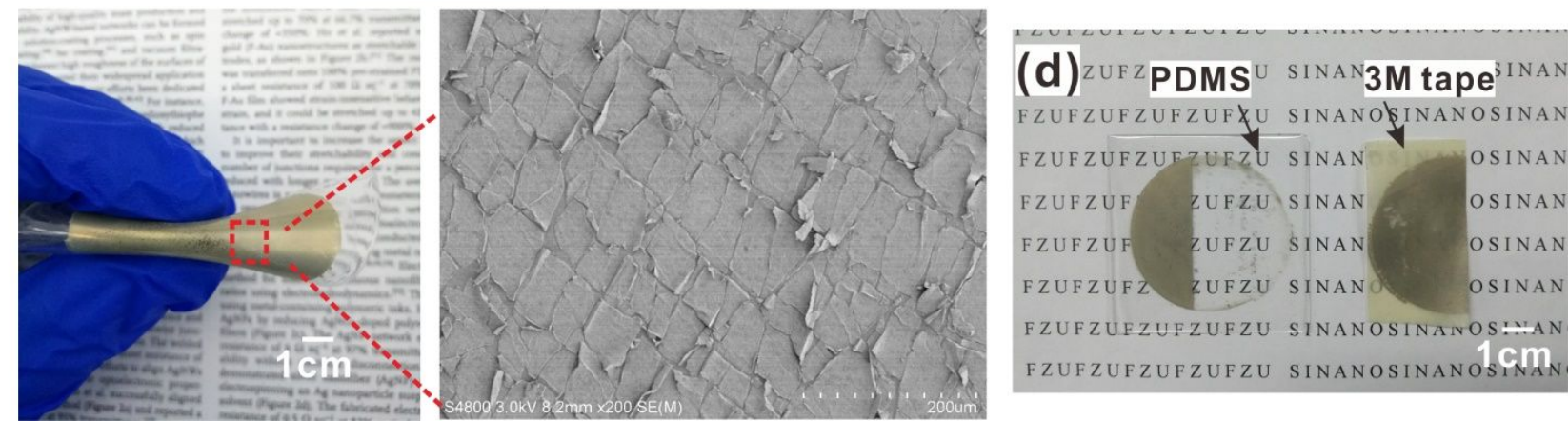

Figure S13. (a) Photograph of the AgNWs/PDMS film (left) and PTFE membrane after thermal pressing process (right); (b) SEM image of PTFE membrane after $60 \mu \mathrm{g} / \mathrm{cm}^{2}$ AgNWs film was transferred to PDMS; (c) Photograph of the AgNWs/PDMS hybrid film in bending state (left) and SEM image of the surface morphology of transferred AgNWs film in bending state (right); (d) Photograph of the AgNWs/PDMS hybrid film after 3M tape adhesion test. The deposition density of AgNWs film is $60 \mu \mathrm{g} / \mathrm{cm}^{2}$.

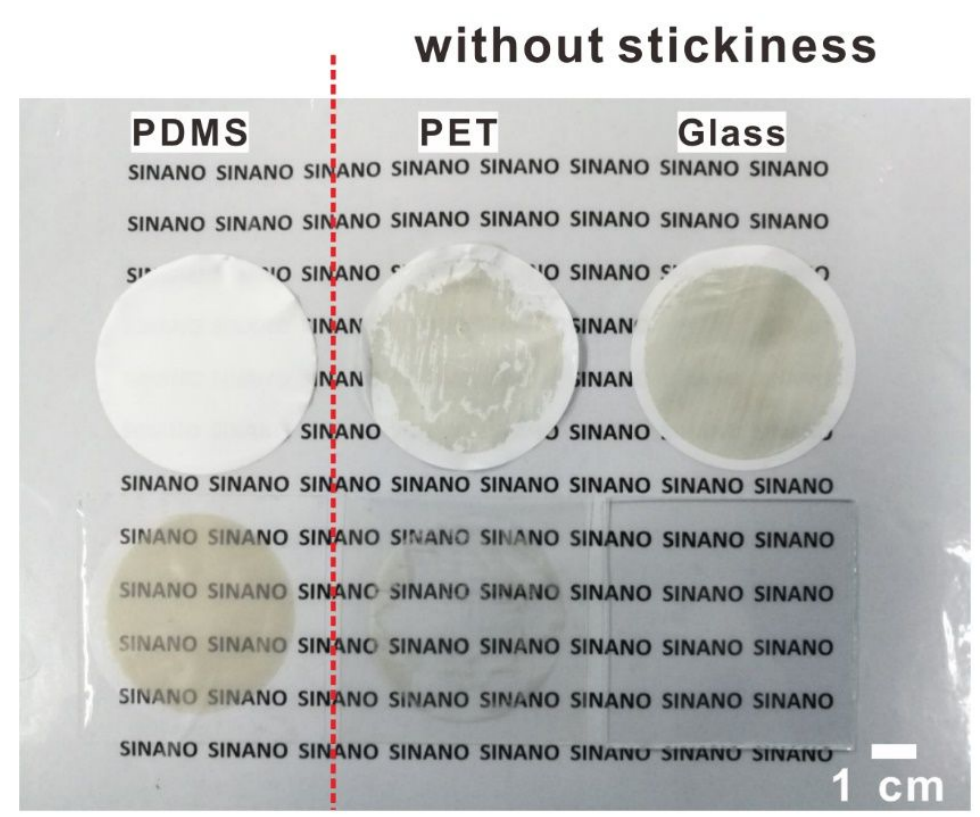

with stickiness

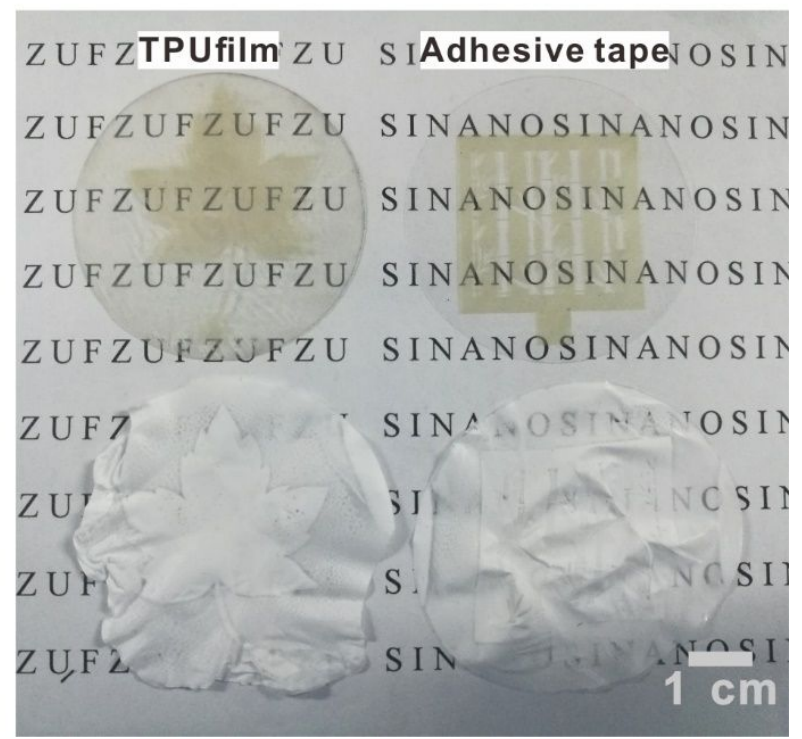

Figure S14. Transfer the deposited Ag NW films onto different substrate by hot pressing method 


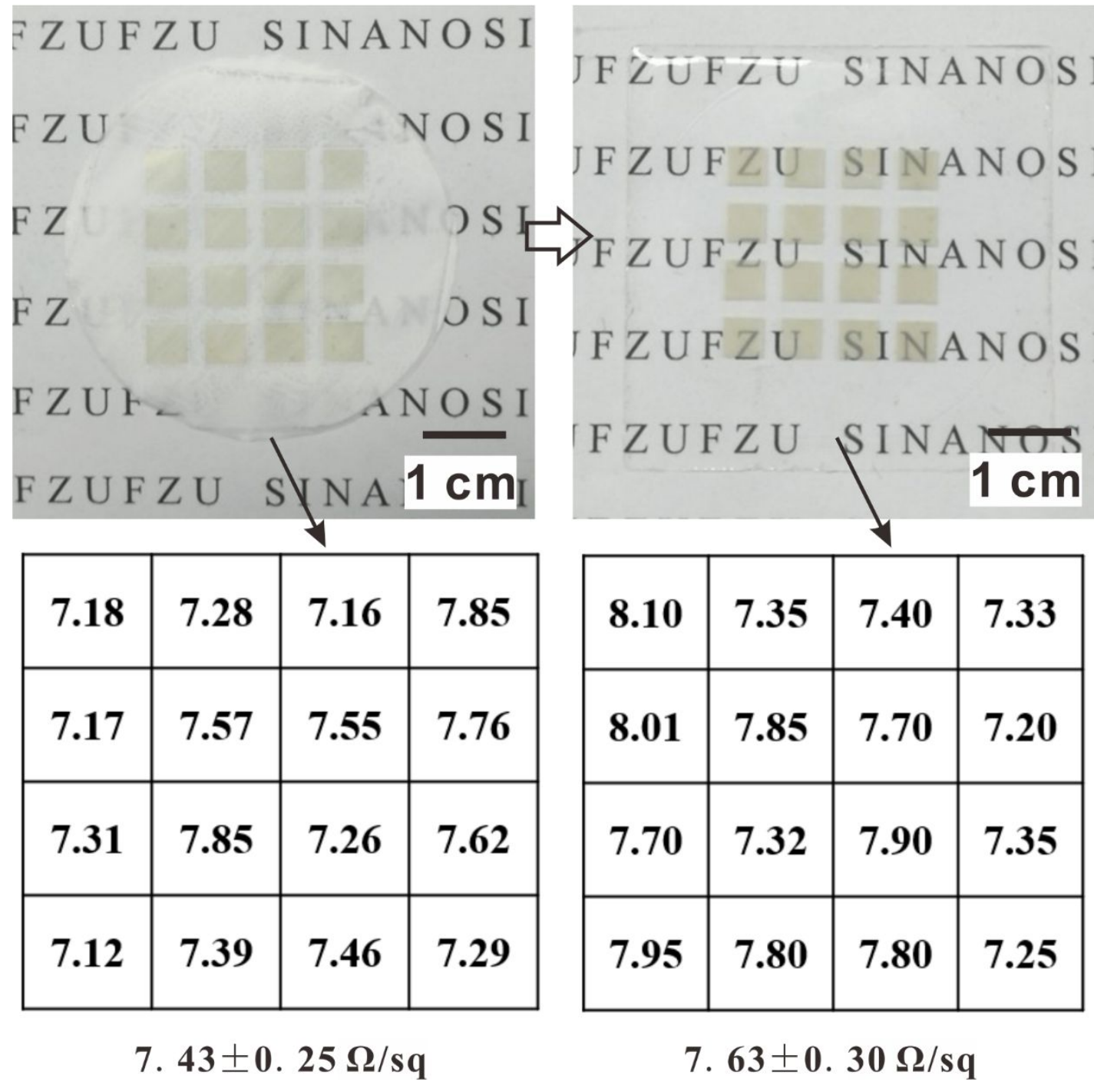

Figure S15. Uniformity of AgNWs patterns on PTFE membrane and after transfer to PDMS. 


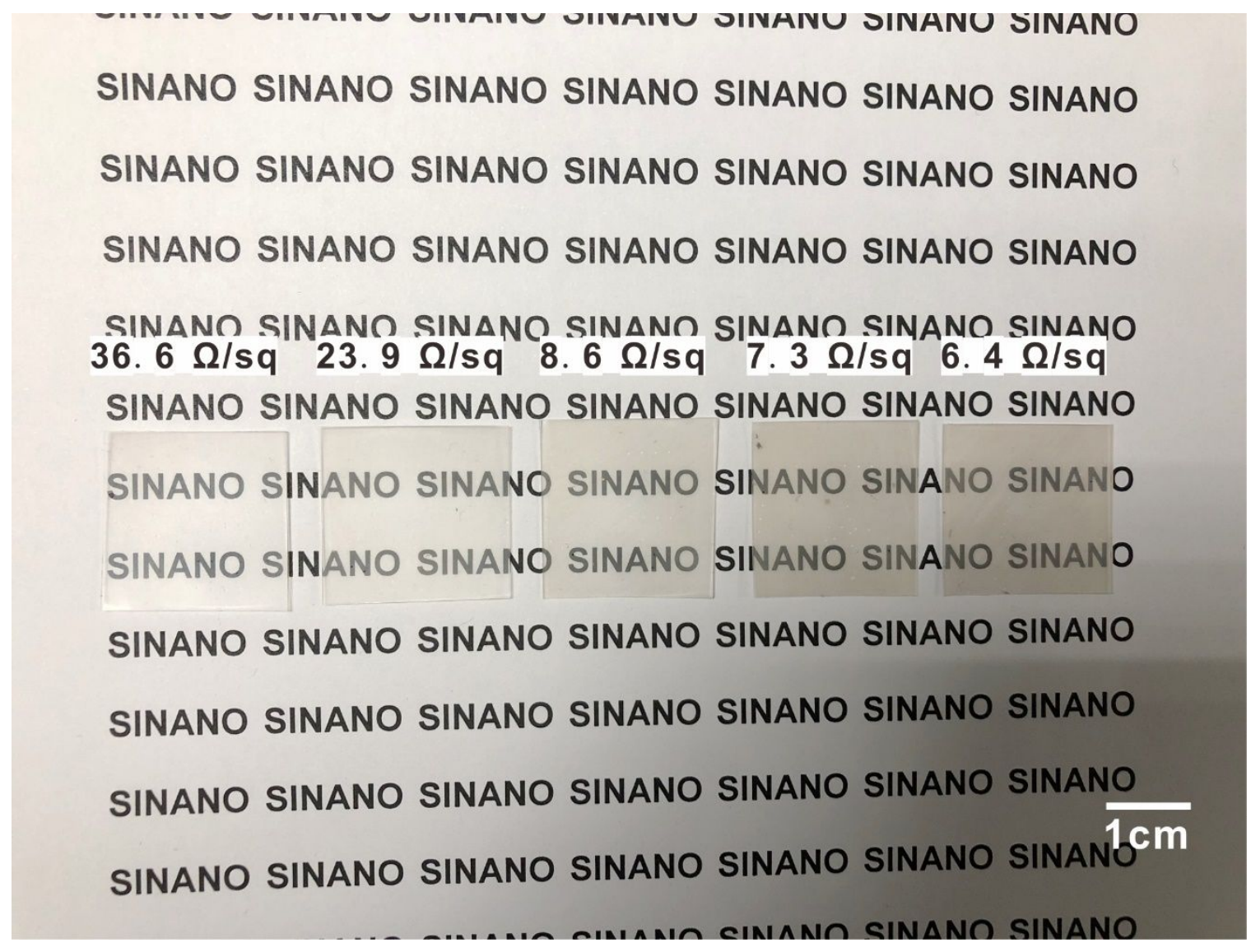

Figure S16. Photograph of TCFs with different sheet resistances
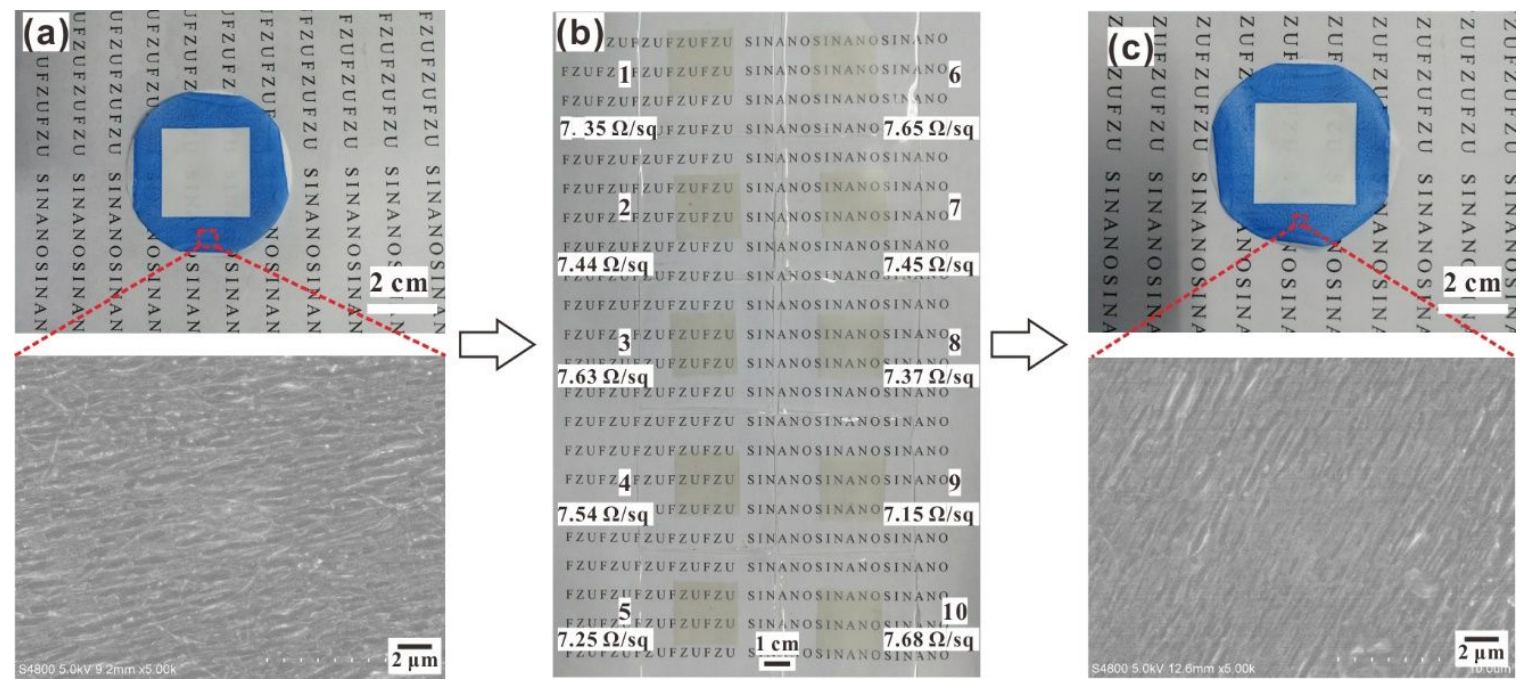

Figure S17. (a) Photograph of the patterned PTFE membrane (upper) and SEM image of the surface morphology of printed PDMS mask (lower) before heat transfer printing, PDMS was dyed blue; (b) Photograph of the asprepared TCFs and the corresponding sheet resistance, the deposition density of AgNWs is $12.5 \mu \mathrm{g} / \mathrm{cm}^{2}$; (c) Photograph of the patterned PTFE membrane (upper) and SEM image of the surface morphology of printed PDMS mask (lower) after repeated 10 times of heat transfer printing. 


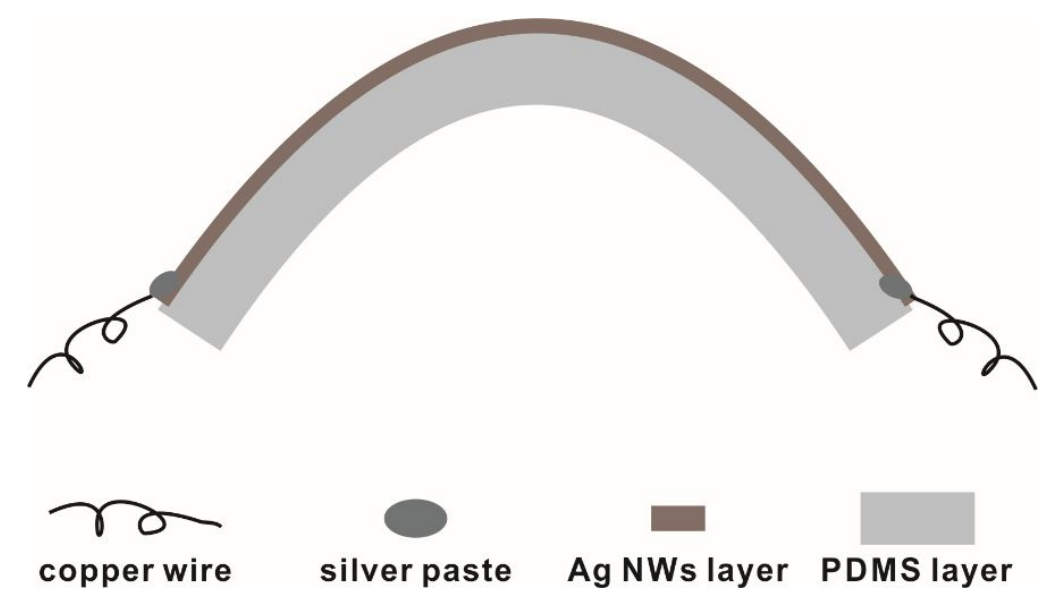

Figure S18. Schematic diagram of bending model for AgNWs/PDMS TCFs.
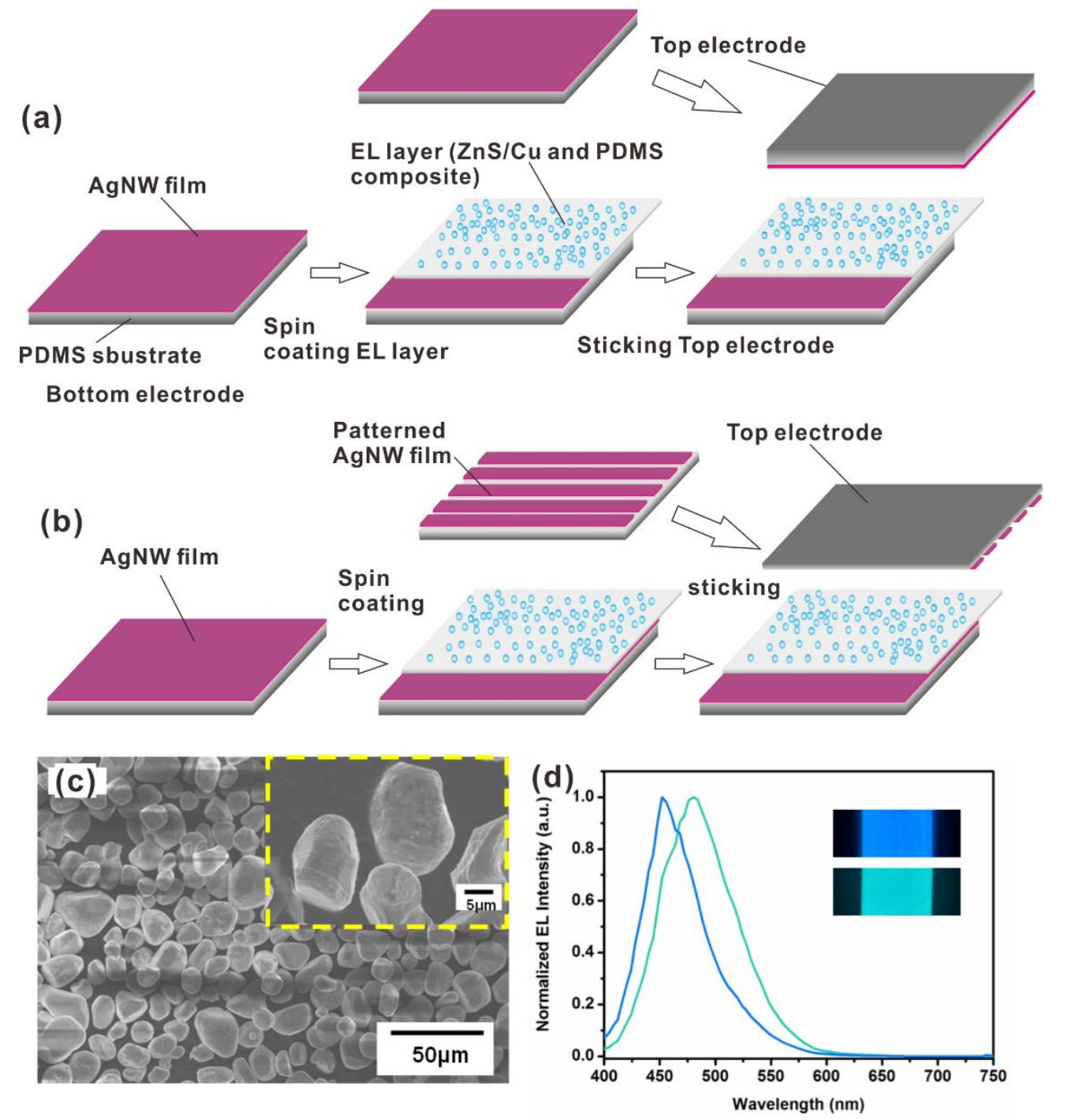

Figure S19. Schematic diagrams of fabrication of stretchable ACEL device (a, b). (c) SEM image of purchased $\mathrm{ZnS}: \mathrm{Cu}$ micro-particles. (d) The emission spectrum of purchased two kinds of $\mathrm{ZnS}: \mathrm{Cu}$ with emission peaks at $452 \mathrm{~nm}$ and $480 \mathrm{~nm}$. 

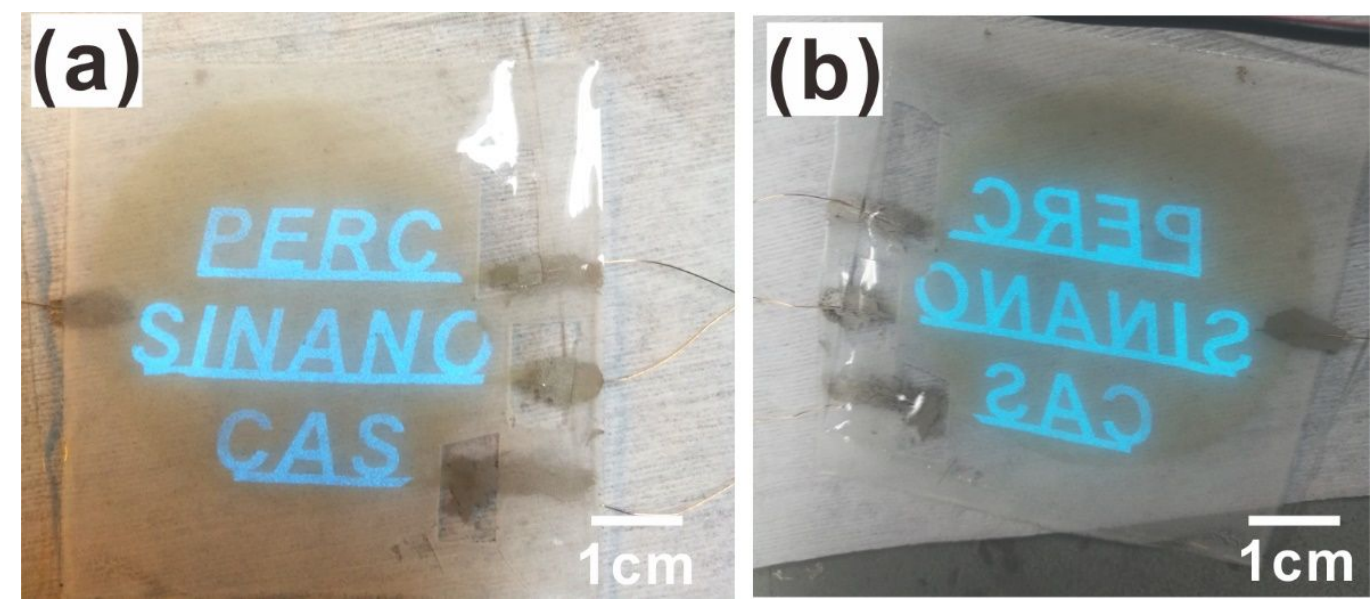

Figure S20. Photographs of the prepared ACEL devices with two-sided luminescence. (a) Front side, (b) Back side
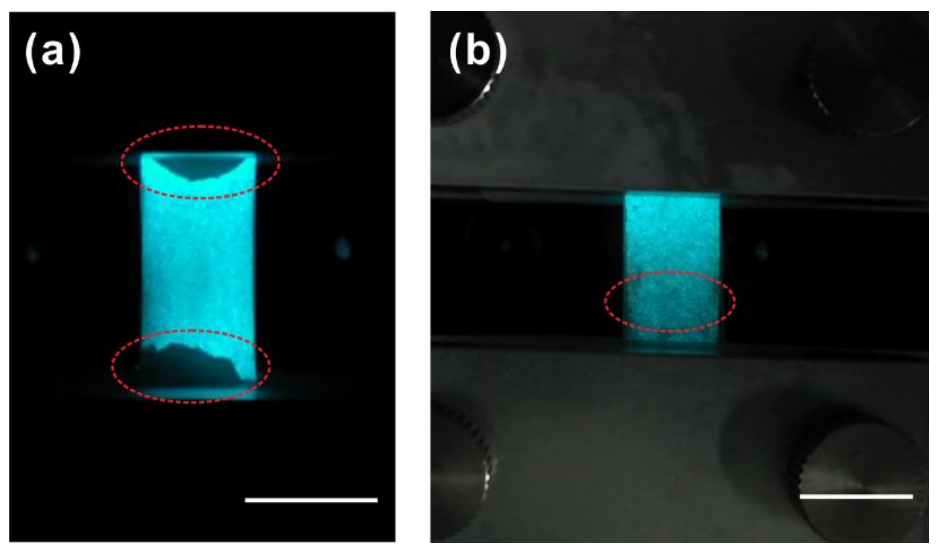

Figure S21. Failure mechanisms of ACEL device under strain. (a) device failure due to mechanical delamination; (b) device failure due to loss of electrical conductivity. (scale bar $1 \mathrm{~cm}$ ).

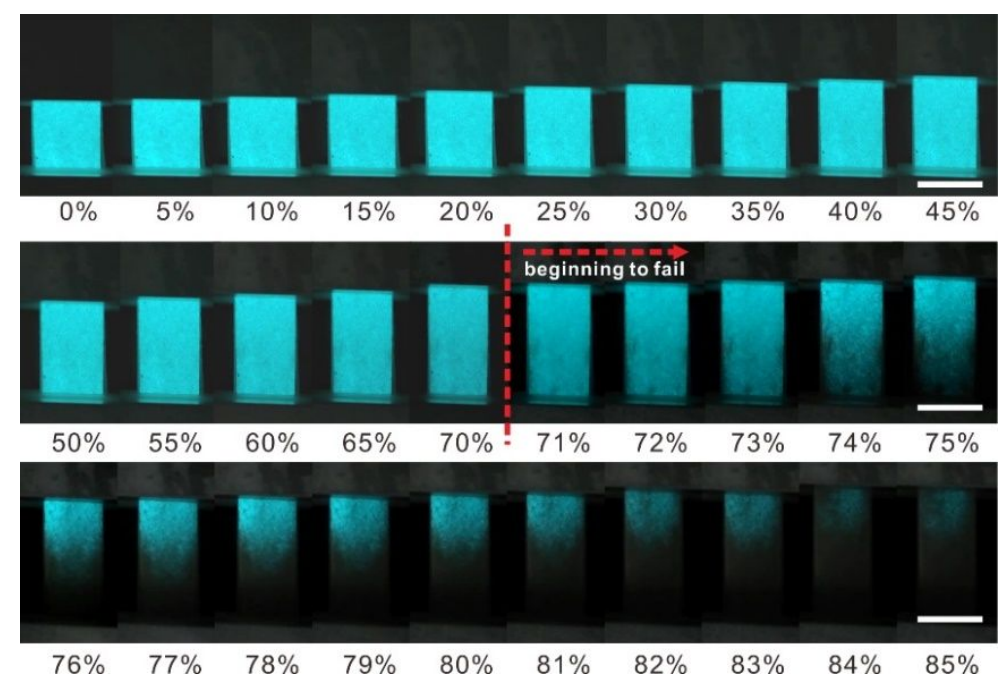

Figure S22. Images of the ACEL device (with $7.3 \Omega /$ sq TCFs) stretched to different strains from $0 \%-85 \%$, scale bar is $1 \mathrm{~cm}$. 


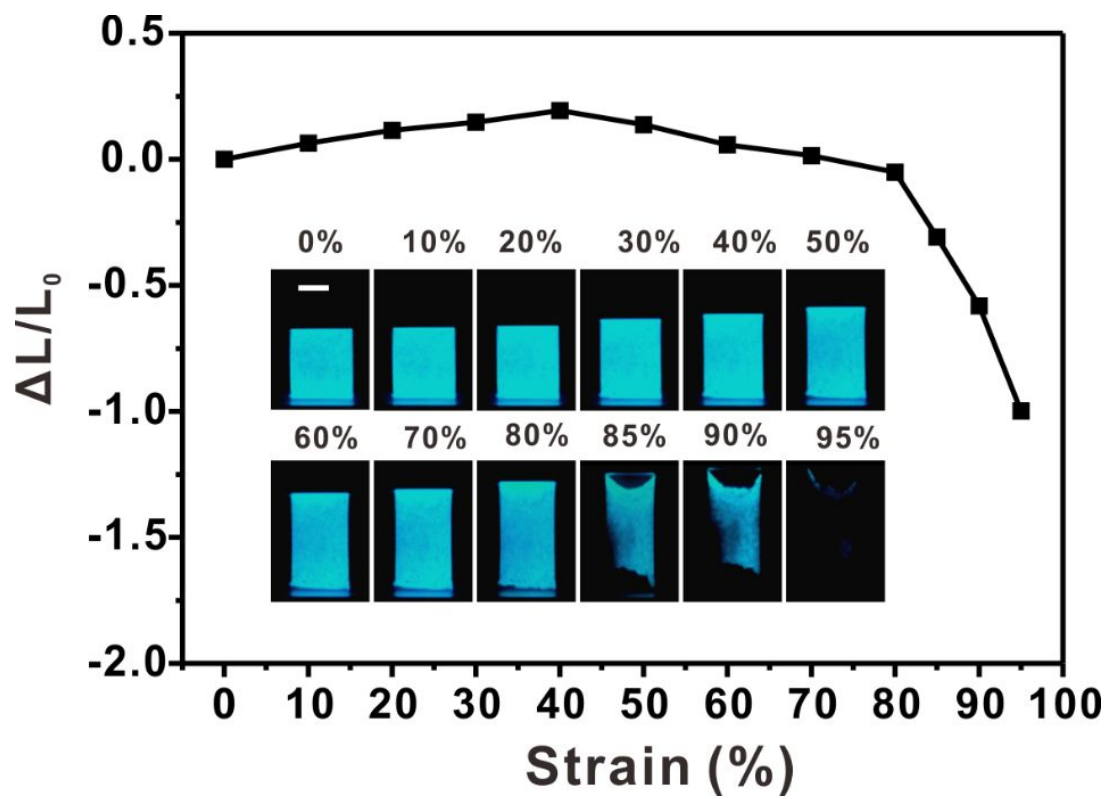

Figure S23. Luminance changes of the ACEL device (with $6.4 \Omega / \mathrm{sq}$ TCFs) under strain from $0 \%-95 \%$, inset: images of the device stretched to different strains, scale bar is $5 \mathrm{~mm}$.

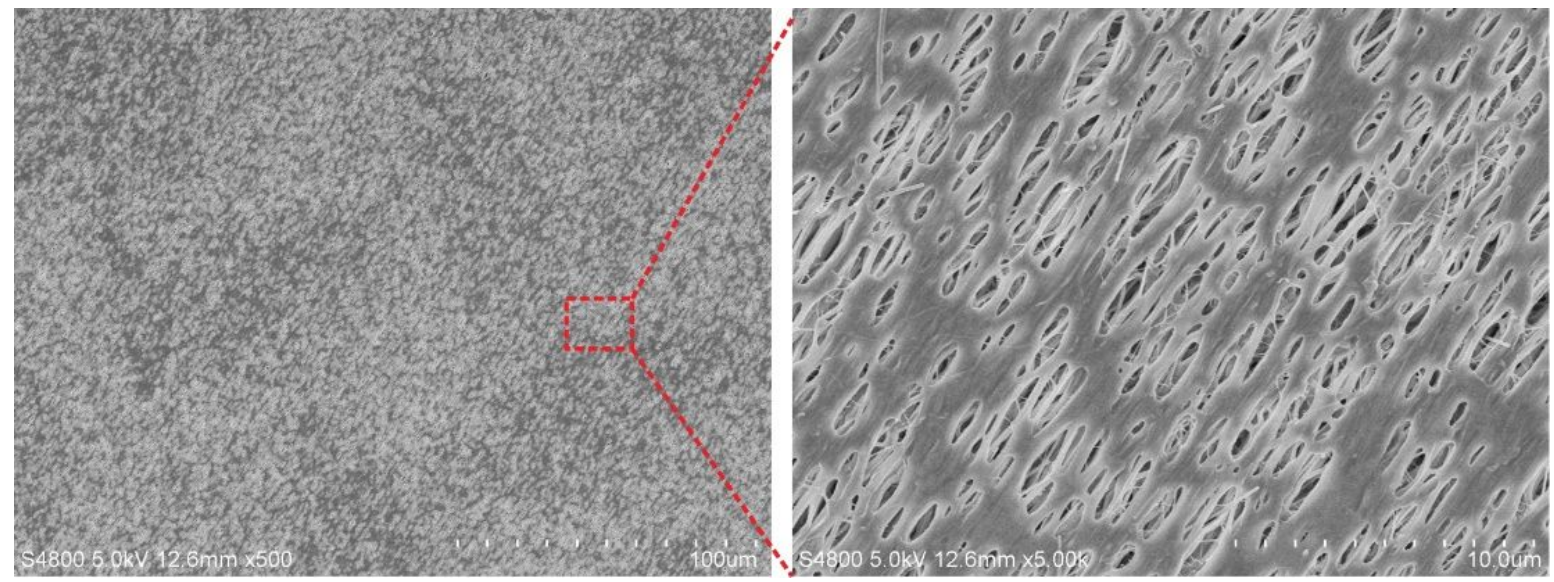

Figure S24. SEM images of the surface morphology of PTFE membrane. 
(a)
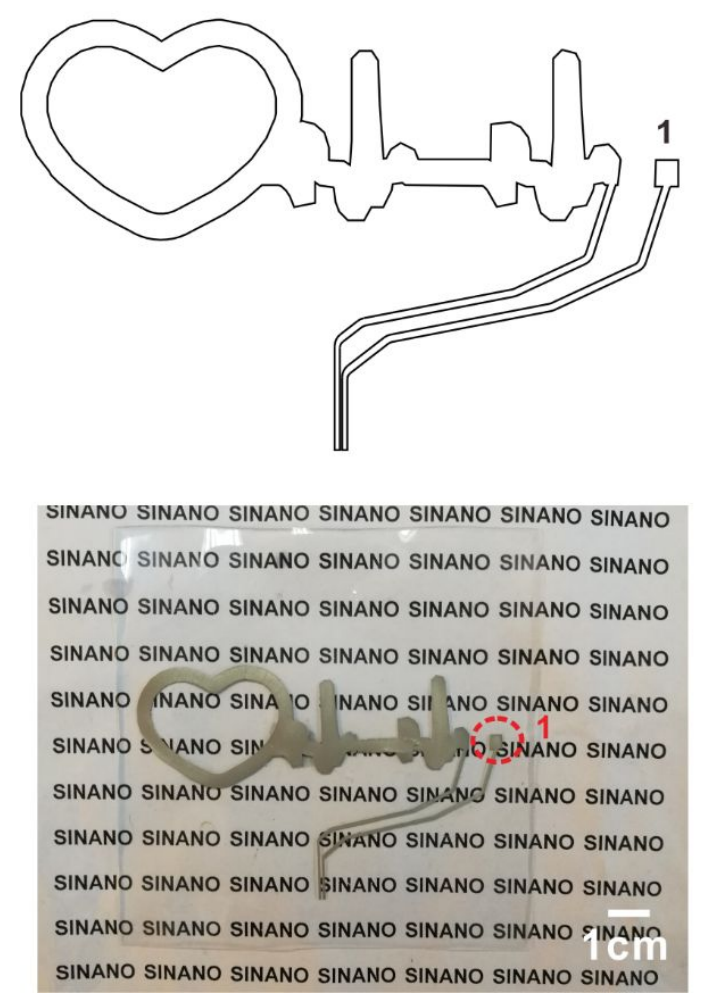

(b)

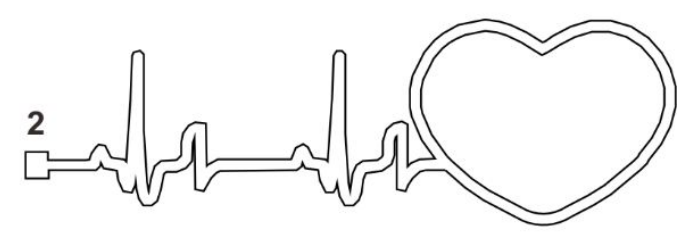

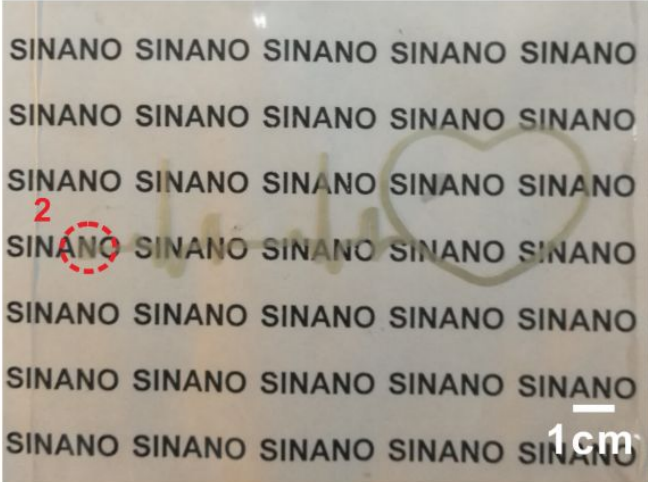

Figure S25. The designed patterns of the flexible circuit board (a) and TCF (b), and the corresponding optical pictures.

\section{Reference:}

[1] Yu, Z.; Zhang, Q.; Li, L.; Chen, Q.; Niu, X.; Liu, J.; Pei, Q. Highly Flexible Silver Nanowire Electrodes for Shape-Memory Polymer Light-Emitting Diodes. Adv. Mater. 2011, 23, 664-668.

[2] Choi, D. Y.; Kang, H. W.; Sung, H. J.; Kim, S. S. Annealing-Free, Flexible Silver Nanowire-Polymer Composite Electrodes via a Continuous Two-Step Spray-Coating Method. Nanoscale 2013, 5, 977-983.

[3] Zhu, S.; Gao, Y.; Hu, B.; Li, J.; Su, J.; Fan, Z.; Zhou, J. Transferable Self-Welding Silver Nanowire Network as High Performance Transparent Flexible Electrode. Nanotechnology 2013, 24, 335202. [4] Ahn, Y.; Lee, H.; Lee, D.; Lee, Y. Highly Conductive and Flexible Silver Nanowire-Based Microelectrodes on Biocompatible Hydrogel. ACS Appl. Mater. Interfaces 2014, 6, 18401-18407. [5] Martinez, V.; Stauffer, F.; Adagunodo, M. O.; Forro, C.; Voros, J.; Larmagnac, A. Stretchable Silver Nanowire-Elastomer Composite Microelectrodes with Tailored Electrical Properties. ACS Appl. Mater. Interfaces 2015, 7, 13467-13475

[6] Fang, Y.; Ding, K.; Wu, Z.; Chen, H.; Li, W.; Zhao, S.; Zhang, Y.; Wang, L.; Zhou, J.; Hu, B. Architectural Engineering of Nanowire Network Fine Pattern for $30 \mu \mathrm{m}$ Wide Flexible Quantum Dot Light Emitting Diode Application. ACS Nano 2016, 10, 10023-10030. 
[7] Yang, B.-R.; Cao, W.; Liu, G.-S.; Chen, H.-J.; Noh, Y.-Y.; Minari, T.; Hsiao, H.-C.; Lee, C.-Y.; Shieh, H.-P. D.; Liu, C. Microchannel Wetting for Controllable Patterning and Alignment of Silver Nanowire with High Resolution. ACS Appl. Mater. Interfaces 2015, 7, 21433- 21441.

[8] Liu, S.; Ho, S.; So, F. Novel Patterning Method for Silver Nanowire Electrodes for ThermalEvaporated Organic Light Emitting Diodes. ACS Appl. Mater. Interfaces 2016, 8, 9268-9274.

[9] Madaria, A. R.; Kumar, A.; Ishikawa, F. N.; Zhou, C. Uniform, Highly Conductive, and Patterned Transparent Films of A Percolating Silver Nanowire Network on Rigid and Flexible Substrates Using a Dry Transfer Technique. Nano Res. 2010, 3, 564-573.

[10] Kim, S.-R.; Kim, J.-H.; Park, J.-W. Wearable and Transparent Capacitive Strain Sensor with High Sensitivity Based on Patterned Ag Nanowire Networks. ACS Appl. Mater. Interfaces 2017, 9, 26407-26416.

[11] Kim, J. -H.; Park, J. -W. Novel Patterning Method for Nanomaterials and Its Application to Flexible Organic Light-Emitting Diodes. ACS Appl. Mater. Interfaces 2018, 10, 9704-9717.

[12] Scheideler, W. J.; Smith, J.; Deckman, I.; Chung, S.; Arias, A. C.; Subramanian, V. A Robust, Gravure-Printed, Silver Nanowire/ Metal Oxide Hybrid Electrode for High-Throughput Patterned Transparent Conductors. J. Mater. Chem. C 2016, 4, 3248-3255.

[13] Cui, Z.; Han, Y.; Huang, Q.; Dong, J.; Zhu, Y. Electrohydrodynamic Printing of Silver Nanowires for Flexible and Stretchable Electronics. Nanoscale 2018, 10, 6806-6811.

[14] Huang, G.-W.; Feng, Q.-P.; Xiao, H.-M.; Li, N.; Fu, S.-Y. Rapid Laser Printing of Paper-Based Multilayer Circuits. ACS Nano 2016, 10, 8895-8903.

[15] Finn, D. J.; Lotya, M.; Coleman, J. N. Inkjet Printing of Silver Nanowire Networks. ACS Appl. Mater. Interfaces 2015, 7, 9254-9261.

[16] Liang, J.; Tong, K.; Pei, Q. A Water-Based Silver-Nanowire Screen-Print Ink for the Fabrication of Stretchable Conductors and Wearable Thin-Film Transistors. Adv. Mater. 2016, 28, 5986-5996.

[17] Li, R.-Z.; Hu, A.; Zhang, T.; Oakes, K. D. Direct Writing on Paper of Foldable Capacitive Touch Pads with Silver Nanowire Inks. ACS Appl. Mater. Interfaces 2014, 6, 21721-21729.

[18] Yang, M.; Kim, S. W.; Zhang, S.; Park, D. Y.; Lee, C.-W.; Ko, Y.-H.; Yang, H.; Xiao, Y.; Chen, G.; Li, M. Facile and Highly Efficient Fabrication of Robust Ag Nanowire-Elastomer Composite Electrodes with Tailored Electrical Properties. J. Mater. Chem. C 2018, 6, 7207- 7218. 